\title{
Pengaruh Dosis Kompos dan Pemangkasan terhadap Pertumbuhan dan Hasil Tanaman Okra (Abelmoschus esculentus L. Moench)
}

\author{
The Effect of Compost Dosage and Pruning on Growth and Yield of Okra Plants \\ (Abelmoschus esculentus L. Moench)
}

\author{
Syarifah Silma Agusti ${ }^{1}$, Erida Nurahmi ${ }^{1}$, Rika Husna ${ }^{1 *}$ \\ ${ }^{1}$ Program Studi Agroteknologi, Fakultas Pertanian, Universitas Syiah Kuala
}

\begin{abstract}
Abstrak. Penelitian ini bertujuan untuk mengetahui pengaruh dosis kompos dan pemangkasan terhadap pertumbuhan dan hasil tanaman okra. Penelitian ini dilaksanakan di Kebun Percobaan dan Laboratorium Hortikultura Fakultas Pertanian Universitas Syiah Kuala Darussalam Banda Aceh, dari bulan Mei sampai Agustus 2018. Penelitian ini menggunakan Rancangan Acak Kelompok (RAK) pola faktorial 4x2 dengan 3 ulangan dan dilanjutkan dengan uji Beda Nyata Jujur taraf 5\% pada hasil uji F yang signifikan. Faktor pertama adalah dosis kompos dengan 4 taraf yaitu: 0, 75, 150, dan 225 g.polibag ${ }^{-1}$. Faktor kedua adalah pemangkasan dengan 2 taraf yaitu: pemangkasan dan tanpa pemangkasan. Parameter yang diamati adalah tinggi tanaman, diameter pangkal batang, jumlah buah per tanaman, panjang buah, total berat buah per tanaman, berat berangkasan basah, dan Indeks panen. Hasil penelitian menunjukkan bahwa, perlakuan dosis kompos berpengaruh sangat nyata terhadap tinggi tanaman umur 45 HST dan berpengaruh nyata pada umur 60 HST. Pertumbuhan tanaman okra terbaik terdapat pada dosis kompos 225 g.polibag ${ }^{-1}$. Pemangkasan berpengaruh nyata terhadap tinggi tanaman umur $60 \mathrm{HST}$, parameter pertumbuhan dan hasil terbaik terdapat pada perlakuan pemangkasan. Kombinasi perlakuan terbaik antara dosis kompos dan pemangkasan terhadap pertumbuhan dan hasil tanaman okra terdapat pada dosis kompos 225 g. polibag $^{-1}$ dengan pemangkasan.
\end{abstract}

Kata kunci: kompos, pemangkasan, tanaman okra

Abstract. This study aims to determine the effect of compost dosage and pruning on the growth and yield of okra plants. This research was conducted at the Experimental Garden and Horticulture Laboratory of the Faculty of Agriculture, Syiah Kuala University, Darussalam Banda Aceh, from May to August 2018. This study used a Randomized Block Design (RBD) factorial pattern $4 \times 2$ with 3 repetation and continued with a 5\% Honest Real Difference test on a significant $\mathrm{F}$ test result. The first factor was compost dosage with 4 levels, namely: 0,75 , 150, and 225 g.polibag-1. The second factor is pruning with 2 levels, namely: pruning and non- pruning. The parameters observed were plant height, stem base diameter, number of fruits per plant, fruit length, and total fruit weight per plant, wet strength weight, and harvest index. The results showed that the treatment of compost dosage had a very significant effect on plant height of $45 \mathrm{HST}$ and had a significant effect on the age of $60 \mathrm{HST}$. The best growth of okra plants is in compost dosage $225 \mathrm{~g}$. Polyibag-1. Pruning has a significant effect on plant height at $60 \mathrm{HST}$, growth parameters and the best result is in pruning treatment. The best combination of treatment between compost dosage and pruning on the growth and yield of the okra plant is in compost dosage $225 \mathrm{~g}$. polybag-1 with pruning.

Keywords: compost, pruning, okra plants 


\section{PENDAHULUAN}

Tanaman okra (Abelmoschus esculentus L. Moench) merupakan sayuran yang berasal dari benua Afrika atau yang dikenal dengan kacang bendi. Saat ini kebutuhan sayuran lebih beraneka ragam karena disamping kebutuhan gizi, rasa dan selera, pemilihan sayuran juga didasarkan atas dasar harga dan penyebaran sayuran tersebut. Salah satu sayuran yang bergizi tinggi adalah okra (Nadira et al., 2009). Tanaman okra selain dijadikan sayuran, bisa dimanfaatkan sebagai obat diantaranya disentri, iritasi lambung, radang tenggorokan (Lim, 2012) dan diabetes mellitus karena bisa menetralkan gula darah dalam tubuh (Amin, 2011).

Upaya yang bisa dilakukan agar produksi okra meningkat yaitu melalui pemupukan. Pupuk dapat mengganti unsur hara yang hilang sehingga tanaman dapat menyerap langsung dalam bentuk yang kompleks dan seimbang, sehingga pemeberian pupuk menjadi faktor yang paling penting di dalam pertumbuhan dan hasil tanaman (Nyanjang et al., 2003).

Penelitian Mariana et al. (2012), penggunaan pupuk anorganik yang berdosiss tinggi pada suatu lahan menyebabkan terjadinya kemerosotan tanah yang disebabkan oleh berkurangnya unsur hara sehingga bahan organik yang ada pada tanah mengalami kemerosotan. Upaya yang bisa lakukan untuk mengurangi pemakaian pupuk anorganik adalah dengan menggunakan pupuk organik yang ramah lingkungan dan tidak merusak alam.

Pupuk organik merupakan pupuk yang mengalami dekomposisi atau penguraian yang berasal dari bagian-bagian makhluk hidup baik itu tumbuhan maupun hewan, seperti pupuk kandang, pupuk hijau, guano, vermikompos dan kompos (Sutedjo, 2010). Kompos merupakan dekomposisi bahan-bahan organik yang terjadi akibat adanya perombakan senyawa kompleks menjadi senyawa yang sederhana dengan bantuan organisme tanah. Pemberian komposs dapat memperbaiki sifat fisik, kimia dan biologi tanah. Komposs terdiri dari berbagai macam bahan dasar organik, salah satu bahan yang dapat dijadikan kompos adalah pupuk kandang, sekam bakar dan sekam.

Menurut Hardjowigeno(2003), penambahan pupuk kandang dapat meningkatkan kesuburan tanah. Menurut Erwiyono (1994), penambahan pupuk kandang pada kompos dapat mempercepat proses dekomposisi sehingga penguraian kompos menjadi lebih cepat. Sekam padi yang telah mengalami proses pembakaran menjadi abu, terdapat banyak unsur hara di antaranya unsur $\mathrm{C}, \mathrm{H}, \mathrm{O}$ dan $\mathrm{S}$ akan tetapi dapat dilepaskan, namun unsur hara $\mathrm{K}$ tetap terikat. Hasil analisis abu sekam didapati bahwa didalam abu sekam terdapat unsur hara $\mathrm{K}$ yang sangat tinggi yang berperan didalam pertumbuhan suatu tanaman sehingga diharapkan dengan pemberian sekam bakar dapat dapat membantu penambahan unsur hara pada tanah serta dapat meningkatkan $\mathrm{pH}$ tanah sehingga struktur pada tanah menjadi lebih baik (Tamtomo et al., 2015).

Penelitian Tamtomo et al. (2015) menunjukkan bahwa ubi jalar yang diberikan kompos jerami padi 20 ton $\mathrm{ha}^{-1}$ dan abu sekam 20 ton $\mathrm{ha}^{-1}$ berpengaruh nyata terhadap pertumbuhan dan produksi terhadap parameter jumlah cabang, panjang batang, jumlah daun berat umbi per tanaman, berat umbi per petak dan kandungan pati umbi.

Selain pemupukan, pemangkasan juga merupakan suatu usaha dalam meningkatkan hasil produksi tanaman, dimana dengan melakukan pemangkasan cabang-cabang produktif akan memacu pertumbuhan sehingga buah yang terbentuk dapat meningkat . Pemangkasan pada tanaman okra dilakukan saat tanaman berumur 30 HST pada daun ke-3, ke-4 dan ke-5. Pemangkasan pada tanaman okra memberikan hasil yang terbaik dibandingkan tanpa pemangkasan pada beberapa parameter seperti tinggi tanaman, jumlah buah muda per tanaman, dan hasil buah muda per hektar (Nadira et al., 2009).

Berdasarkan uraian diatas maka perlu dilakukan penelitian mengenai pengaruh dosis kompos dan pemangkasan terhadap pertumbuhan dan hasil tanaman okra. 


\section{METODE PENELITIAN}

Penelitian ini dilaksanakan dari tanggal 30 Mei sampai dengan tanggal 11 Agustus 2018 di Kebun Percobaan dan Laboratorium Hortikultura Jurusan Agroteknologi Fakultas Pertanian Universitas Syiah Kuala Darussalam Banda Aceh.

\section{Alat}

Alat yang digunakan dalam penelitian ini adalah cangkul, meteran, timbangan analitik, ajir, jangka sorong, gembor, penggaris, pinset, gunting, kertas label dan alat tulis.

\section{Bahan}

Bahan yang digunakan dalam penelitian ini berupa benih okra hijau varitas Naila IPB sebanyak 144 biji, tanah, polibag ukuran $50 \mathrm{~cm}$ x $50 \mathrm{~cm}$ (isi $15 \mathrm{~kg}$ ), pupuk Urea sebanyak 81 g, pupuk SP36 sebanyak 103,68 g, pupuk $\mathrm{KCl}$ sebanyak 40,32 g, kompos sebanyak 8,1 kg.

\section{Metode Penelitian}

Penelitian ini menggunakan Rancangan Acak Kelompok (RAK) Faktorial dengan 2 faktor dengan pola $4 \times 2$ dengan 3 ulangan sehingga terdapat 24 satuan percobaan. Pada setiap satuan percobaan terdapat 3 tanaman sehingga terdapat 72 tanaman.Faktor pertama dosis kompos terdiri atas 4 taraf yaitu: $\mathrm{K}_{0}=0$ g.polibag ${ }^{-1}, \mathrm{~K}_{1}=75$ g.polibag ${ }^{-1}, \mathrm{~K}_{2}=150$ g.polibag ${ }^{-1}, \mathrm{~K}_{3}=$ 225 g.polibag $^{-1}$. Faktor kedua pemangkasan terdiri atas 2 taraf yaitu: $\mathrm{P}_{0}=$ Tanpa pemangkasan dan $\mathrm{P}_{1}=$ Pemangkasan .

\section{Pelaksanaan Penelitian \\ Persiapan Media Tanam}

Media tanam yang digunakan adalah campuran lapisan tanah dan kompos. Campuran kompos terdiri dari pupuk kandang, sekam padi, dan sekam bakar yang diperoleh dari HIMAILTA (Himpunan Mahasiswa Ilmu Tanah) Fakultas Pertanian Universitas Syiah Kuala. Campuran tanah dan kompos sesuai dengan masing-masing perlakuan yaitu 0, 75, 150, 225 g.polibag $^{-1}$. Campuran media tanam tersebut kemudian dimasukkan kedalam polibag ukuran $50 \mathrm{~cm}$ x $50 \mathrm{~cm}$ (isi $15 \mathrm{~kg}$ ).

\section{Pemasangan Label}

Pemasangan label dilakukan sebelum melakukan penanaman di sesuaikan dengan kombinasi perlakuan.

\section{Penanaman}

Penanaman benih dapat dilakukan dengan menanam biji secara langsung. Biji okra ditanam dengan cara memasukkan 2 butir biji per polibag dengan kedalaman $4 \mathrm{~cm}$. Setelah tanaman berumur 2 minggu disisakan satu tanaman per polybag yang baik pertumbuhannya dan akan dipelihara hingga panen.

\section{Pemangkasan}

Saat tanaman okra berumur 30 hari setelah tanam (HST) dilakukan pemangkasan pada daun ke 3, 4, dan 5. Pemangkasan dilakukan pada ketiak tangkai daun dengan menggunakan pisau yang bersih ( Nadira et al., 2009).

\section{Pemeliharaan}

Penyiraman dilakukan dua kali dalam sehari yaitu pagi dan sore hari, namun bila hujan tidak dilakukan penyiraman. Penyiangan gulma dilakukan secara manual sesuai dengan keadaan di lapangan. Di lakukan pemupukan pupuk anorganik sebagai pupuk dasar yaitu 
Urea (1,125 g.polibag $\left.{ }^{-1}\right)$, SP-36 (1,44 g.polibag $\left.{ }^{-1}\right)$ dan KCL (0,56 g.polibag $\left.{ }^{-1}\right)$ yang diberikan pada saat tanaman berumur 14 HST. Pengendalian hama dan penyakit dilakukan jika tanaman terserang OPT, hama yang menyerang tanaman okra yaitu kutu daun, tanaman okra terserang hama pada saat tanaman berumur 18 dan 26 HST, pengendalian hama pada tanaman dilakukan dengan menggunakan Decis 25 EC dengan dosis $1 \mathrm{cc}$ liter air $^{-1}$.

\section{Pemanenan.}

Pemanenan okra dapat dilakukan pada tanaman berumur 55 hari setelah tanam atau 5-6 hari setelah tanaman berbunga. Waktu panen okra yang baik adalah pagi dan sore. Buah okra yang baik untuk dipanen adalah buah yang masih muda yang berukuran $5-10 \mathrm{~cm}$, ujung buah mudah di patahkan berwarna putih dan berlendir. Panen okra dilakukan dengan menggunakan pisau yang tajam karena tangkai okra sangat lentur.

\section{Parameter Pengamatan}

\section{Tinggi Tanaman (cm)}

Pengamatan tinggi tanaman dilakukan pada saat tanaman berumur 15, 30, 45 dan 60 HST. Pengukuran dilakukan dengan menggunkaan meteran dari pangkal batang sampai titik tumbuh. Pangkal yang telah diukur diberikan tanda untuk memudahkan pengukuran tinggi tanaman selanjutnya.

\section{Diameter Pangkal Batang (mm)}

Pengamatan diameter pangkal batang diukur menggunakan jangka sorong pada saat tanaman berumur 15, 30, 45 dan 60 HST. Pangkal batang yang telah diukur diberikan tanda berupa label untuk memudahkan pengukuran tinggi tanaman selanjutnya.

\section{Jumlah Buah per Tanaman ( buah)}

Pengamatan jumlah buah dilakukan dengan menghitung jumlah buah pertanaman setiap kali panen selama 5 kali panen dengan interval waktu pemanenan 2 hari sekali.

\section{Panjang Buah (cm)}

Pengukuran panjang buah dilakukan dengan mengukur panjang buah yang diawali dari pangkal buah sampai ujung buah. Panjang buah yang disajikan merupakan rata-rata panjang buah selama 5 kali panen.

\section{Total Berat Buah Pertanaman ( g)}

Perhitungan berat buah dilakukan dengan menimbang berat buah. Berat buah yang disajikan merupakan berat total buah selama 5 kali panen.

\section{Berat Berangkasan Basah (g)}

Perhitungan bobot berangkasan basah dilakukan dengan menimbang berat basah tanaman. Bobot berangkasan basah tanaman yang disajikan merupakan berat total berangkasan basah setelah pemanenan.

\section{Indeks Panen}

Pengukuran indeks panen dilakukan pada saat akhir penelitian yaitu membagi total berat buah per tanaman dengan berat berangkasan basah tanaman.

\section{HASIL DAN PEMBAHASAN}

\section{Pengaruh Dosis Kompos terhadap Pertumbuhan dan Hasil Tanaman Okra}

Hasil Uji F pada analisis ragam menunjukkan bahwa, pemberian dosis kompos berpengaruh sangat nyata pada tinggi tanaman umur 45 HST dan berpengaruh nyata terhadap tinggi tanaman umur 60 HST. 
Tabel 1. Rata-rata Pertumbuhan dan Hasil Tanaman Okra Akibat Perlakuan Dosis Kompos

\begin{tabular}{|c|c|c|c|c|c|}
\hline \multirow[t]{2}{*}{ Parameter } & \multicolumn{4}{|c|}{$\begin{array}{c}\text { Dosis Kompos } \\
\text { (g.polibag }{ }^{-1} \text { ) }\end{array}$} & \multirow[t]{2}{*}{$\mathrm{BNJ}_{0,05}$} \\
\hline & $\begin{array}{c}0 \\
\left(\mathrm{~K}_{0}\right)\end{array}$ & $\begin{array}{c}75 \\
\left(K_{1}\right)\end{array}$ & $\begin{array}{l}150 \\
\left(\mathrm{~K}_{2}\right)\end{array}$ & $\begin{array}{l}225 \\
\left(\mathrm{~K}_{3}\right)\end{array}$ & \\
\hline Tinggi Tanaman 15 HST & 10,18 & 10,29 & 10,52 & 10,17 & - \\
\hline Tinggi Tanaman 30 HST & 29,11 & 31,44 & 32,04 & 32,87 & - \\
\hline Tinggi Tanaman 45 HST & $42,05^{\mathrm{a}}$ & $49,29^{\mathrm{b}}$ & $47,34^{\mathrm{b}}$ & $51,67^{\mathrm{b}}$ & 5,21 \\
\hline Tinggi Tanaman 60 HST & $56,73^{\mathrm{a}}$ & $60,55^{\mathrm{ab}}$ & $60,,^{34 a b}$ & $64,93^{\mathrm{b}}$ & 6,57 \\
\hline Diameter Pangkal Batang 15 HST & 3,44 & 3,55 & 3,73 & 3,48 & - \\
\hline Diameter Pangkal Batang 30 HST & 10,18 & 9,56 & 10,37 & 10,59 & - \\
\hline Diameter Pangkal Batang 45 HST & 13,33 & 13,94 & 14,00 & 14,54 & - \\
\hline Diameter Pangkal Batang 60 HST & 20,09 & 20,33 & 21,21 & 21,62 & - \\
\hline Jumlah Buah per Tanaman & 5,66 & 5,67 & 6,00 & 6,33 & - \\
\hline Panjang Buah & 15,22 & 16,05 & 16,03 & 15,95 & - \\
\hline Berat Buah per Tanaman & 136,08 & 151,89 & 154,88 & 147,97 & - \\
\hline Berat Berangkasan Basah & 620,34 & 599,28 & 622,15 & 650,29 & - \\
\hline Indeks Panen & 0,26 & 0,26 & 0,26 & 0,28 & - \\
\hline
\end{tabular}

Keterangan : Angka yang diikuti oleh huruf yang sama pada baris yang sama berbeda tidak nyata pada taraf 0.05 (Uji BNJ)

Tabel 2 menunnjukkan bahwa pemberian dosis kompos berpengaruh sangat nyata terhadap tinggi tanaman umur 45 HST dan 60 HST, namun tidak berpengaruh nyata terhadap semua parameter hasil tanaman okra. Pemberian dosis kompos yang diberikan kepada tanaman okra pada umur 15 dan 30 HST berpengaruh tidak nyata terhadap tinggi tanaman. Hal ini diduga bahwa pemberian dosis kompos belum terdekomposisi dengan sempurna sehingga menyebabkan kandungan Nitrogen yang terdapat pada kompos belum mampu meningkatkan pertumbuhan tinggi tanaman pada umur 15 dan 30 HST.

Tanaman okra tertinggi pada umur 45 HST terdapat pada perlakuan dosis kompos 225 g.polibag ${ }^{-1}$ yang berbeda nyata dengan dosis kompos 0 g.polibag ${ }^{-1}$, namun berbeda tidak nyata dengan pemberian dosis kompos 75 g.polibag ${ }^{-1}$ dan 150 g.polibag ${ }^{-1}$. Sedangkan tanaman okra tertinggi pada umur 60 HST terdapat pada perlakuan dosis kompos 225 g.polibag $^{-1}$ yang berbeda nyata dengan pemberian dosis kompos 0 g.polibag ${ }^{-1}$, namun berbeda tidak nyata dengan pemberian dosis kompos 75 g.polibag ${ }^{-1}$ dan 150 g.polibag ${ }^{-1}$. Hal ini menunjukkan bahwa kompos yang diberikan dengan dosis yang tinggi menyebabkan unsur hara semakin banyak tersedia bagi tanaman sehingga penambahan kompos selain dapat meningkatkan kadar hara tanah juga dapat memperbaiki sifat fisik tanah.

Terjadinya peningkatan tinggi tanaman pada umur 45 HST dan 60 HST di duga bahwa bahan organik yang diberikan telah terdekomposisi dengan sempurna sehingga unsur hara sudah cukup tersedia secara optimal pada tanah sehingga dapat memacu proses pertumbuhan tanaman. Pada pertumbuhan tinggi tanaman, salah satu unsur yang sangat berperan adalah Nitrogen. Sumber nitrogen dapat ditemukan pada bahan organik yang ada pada media tanam (Ginting et al.,1996). Menurut Djunaedi (2009) meningkatkan unsur $\mathrm{N}$ di dalam tanah disebabkan oleh bahan organik yang sudah mengalami perombakan sehingga terjadi perbedaan terhadap tinggi tanaman.

Perbedaan dosis kompos yang diberikan kepada tanaman okra tidak memberikan pengaruh yang nyata terhadap parameter hasil. Hal ini diduga karena hasil analisis kandungan hara yang terdapat dalam kompos menunjukkan bahwa kandungan unsur hara Kalium yang sangat rendah yang menyebabkan unsur tersebut tidak dapat diserap dengan baik oleh tanaman sehingga enzim-enzim yang berperan dalam metabolisme tanaman tidak dapat berfungsi 
dengan baik. Mas'ud ( 1993) menyatakan bahwa unsur hara Kalium memiliki peranan penting dalam translokasi fotosintat ke buah sehingga dipengaruhi oleh pergerakan fotosintat dari sel mexofil hingga ke akar sehingga menyebabkan terjadinya perkembangan akar sehingga proses penyerapan hara yang dilakukan oleh akar tanaman bisa meningkat yang menyebabkan fotosintat ke buah menjadi lebih banyak, sehingga akan terjadi peningkatan terhadap berat buah pada tanaman.

\section{Pengaruh Pemangkasan terhadap Pertumbuhan dan Hasil Tanaman Okra}

Hasil Uji F pada analisis ragam menunjukkan bahwa pemangkasan nyata terhadap tinggi tanaman pada umur 60 HST.

Tabel 2. Rata rata Pertumbuhan dan Hasil Tanaman Okra Akibat Perlakuan Pemangkasan

\begin{tabular}{lccc}
\hline \multirow{2}{*}{ Parameter } & \multicolumn{2}{c}{ Pemangkasan } & BNJ $_{0,05}$ \\
\cline { 2 - 3 } & Tanpa Pemangkasan & Pemangkasan & \\
\hline Tinggi Tanaman 15 HST & 10,52 & 10,06 & - \\
Tinggi Tanaman 30 HST & 30,86 & 31,88 & - \\
Tinggi Tanaman 45 HST & 46,25 & 48,93 & - \\
Tinggi Tanaman 60 HST & $58,87^{\mathrm{a}}$ & $62,41^{\mathrm{b}}$ & 3,42 \\
Diameter Pangkal Batang 15 HST & 3,61 & 3,49 & - \\
Diameter Pangkal Batang 30 HST & 9,97 & 10,39 & - \\
Diameter Pangkal Batang 45 HST & 14,27 & 13,64 & - \\
Diameter Pangkal Batang 60 HST & 20,94 & 20,69 & - \\
Jumlah Buah per Tanaman & 5,78 & 6,06 & - \\
Panjang Buah & 15,64 & 15,99 & - \\
Berat Buah per Tanaman & 142,98 & 152,43 & - \\
Berat Berangkasan Basah & 619,46 & 621,20 & - \\
Indeks Panen & 0,26 & 0,28 & - \\
\hline
\end{tabular}

Keterangan : Angka yang diikuti oleh huruf yang sama pada baris yang sama berbeda tidak nyata pada taraf 0.05 (Uji BNJ)

Tabel 2 menunjukkan bahwa perlakuan pemangkasan berpengaruh nyata pada tinggi tanaman umur $60 \mathrm{HST}$. Hal ini menunjukkan bahwa perlakuan pemangkasan pada daun ke 3, 4, dan 5 mampu meningkatkan pertumbuhan tinggi tanaman pada umur 60 HST. Hal ini diduga bahwa pemangkasan daun bawah pada tanaman okra menyebabkan fotosintat lebih diarahkan ke pertumbuhan sehingga akan memacu pertumbuhan tinggi tanaman sedangkan tanpa pemangkasan fotosintat akan didistribusikan ke banyak cabang.

Menurut Gardner et al. (1991), hasil dari fotositensis disalurkan ke bagian meristem yang terdapat diujung batang serta terbentuknya sel-sel baru sehingga terjadinya penambahan tinggi pada tanaman. Hal ini juga didukung oleh pendapat Khan et al. (2002) menyatakan bahwa pemangkasan yang dilakukan pada daun bawah dapat menyokong hasil tanaman dibandingkan dengan pemangkasan yang dilakukan pada daun bagian atas, hal ini disebabkan karena fotositensis sangat aktif dilakukan pada daun bagian atas dibandingkan dengan daun bagian bawah sehingga menyebabkan cahaya matahari hanya tersentralisasi pada daun lapisan atas.

Perlakuan pemangkasan yang diuji tidak memberikan pengaruh yang nyata terhadap parameter hasil tanaman okra. Akan tetapi, secara keseluruhan perlakuan pemangkasan cenderung menghasilkan jumlah buah, panjang buah, dan berat buah tertinggi. Hal ini diduga bahwa pemangkasan daun ke 3,4 dan 5 pada tanaman okra belum mampu menyokong hasil tanaman okra. Hal ini sesuai dengan pernyataan Suminarti (2000) yang menyatakan bahwa besar kecilnya dampak yang ditimbulkan akibat pemangkasan dipengaruhi oleh banyak atau sedikitnya daun yang diambil atau letak daun untuk dilakukan pemangkasan. 


\section{Pengaruh Interaksi Dosis Kompos dan Pemangkasan terhadap Pertumbuhan dan Hasil Tanaman Okra}

Hasil Uji F pada analisis ragam menunjukkan bahwa terdapat interaksi yang sangat nyata terhadap tinggi tanaman okra pada umur 45 HST.

Tabel 3. Rata rata Tinggi Tanaman Okra umur 45 HST Akibat Interaksi Antara Dosis Kompos dan Pemangkasan

Dosis Kompos (g.polibag-1)

\begin{tabular}{lllll}
\cline { 2 - 3 } Pemangkasan & 0 & 75 & 150 & 225
\end{tabular} BNJ $_{0,05}$

\begin{tabular}{llllll}
\hline $\mathrm{P}_{0}$ & $42,93^{\mathrm{Aa}}$ & $46,87^{\mathrm{ABa}}$ & $50,28^{\mathrm{Bb}}$ & $44,93^{\mathrm{Aa}}$ & \\
$\mathrm{P}_{1}$ & $41,17^{\mathrm{Aa}}$ & $51,72^{\mathrm{Ba}}$ & $44,41^{\mathrm{Aa}}$ & $58,42^{\mathrm{Cb}}$ & 4,99
\end{tabular}

Keterangan : Angka yang diikuti oleh huruf yang sama berbeda tidak nyata pada taraf 0,05 (Uji BNJ). Huruf kapital merupakan notasi pada baris, huruf kecil merupakan notasi pada kolom.

Tabel 3 menunjukkan bahwa terdapat interaksi sangat nyata terhadap tinggi tanaman umur 45 HST.

Kombinasi perlakuan menghasilkan pertumbuhan tertinggi dengan pemberian dosis kompos 225 g.polibag ${ }^{-1}$ dengan pemangkasan $\left(\mathrm{P}_{1}\right)$. Hal ini sesuai dengan pendapat Firoz (2009) yang menyatakan bahwa pembelahan sel dan pembentukan jaringan disebabkan oleh dosis $\mathrm{N}$ pada kompos yang tinggi sehingga terjadi peningkatan pada pertumbuhan vegetatif tanaman.

Pertumbuhan tinggi tanaman dipengaruhi oleh auksin yang dihasilkan oleh ujung apikal dan sitokinin yang ditransport dari akar. Sitokinin berperan dalam memaacu pembelahan sel melalui peningkatan laju sintesis protein sehingga memacu pertumbuhan tinggi tanaman. Hormon auksin dan nutrisi yang semula berada di bagian apical tidak lagi di kirim ke bagian tangkai daun yang sudah dilakukan pemangkasan tetapi langsung membelah pada ujung batang tanaman yang sedang aktif tumbuh (Lakitan, 1996).

Sedangkan parameter pertumbuhan dan hasil tanaman okra lainnya menunjukkan interaksi yang tidak nyata antara perlakuan dosis kompos dengan pemangkasan. Hal ini disebabkan bahwa diantara kedua perlakuan tersebut tidak ada yang saling menunjukkan interaksi pengaruh nyata pada parameter yang diamati.

\section{KESIMPULAN DAN SARAN}

Perlakuan dosis kompos berpengaruh sangat nyata terhadap tinggi tanaman umur 45 HST dan berpengaruh nyata terhadap tinggi tanaman umur 60 HST. Pertumbuhan dan hasil tanaman okra memberikan hasil terbaik pada dosis kompos 225 g.polibag ${ }^{-1}$. Perlakuan pemangkasan berpengaruh nyata terhadap tinggi tanaman okra pada umur 60 HST. Pertumbuhan dan hasil terbaik terdapat pada perlakuan pemangkasan. Terdapat interaksi yang sangat nyata antara perlakuan dosis kompos dengan pemangkasan terhadap tinggi tanaman pada umur 45 HST, namun tidak terdapat interaksi yang nyata pada parameter pengamatan yang lainnya.

Perlu dilakukan penelitian lebih lanjut di bedengan mengenai penggunaan dosis kompos terhadap perlakuan pemangkasan dan tanpa pemangkasan serta perlu di terapkan beberapa teknik pemangkasan agar pengaruh dosis kompos dan pemangkasan dapat terlihat jelas pada pertumbuhan dan hasil tanaman okra. 


\section{DAFTAR PUSTAKA}

Amin, I. M. 2011. Nutritional properties of Abelmoschus esculentus as remedy to manage diabetes mellitus : A literatire review. International Conference on Biomedical Engineering and Technologi. IACSIT Press. Singapore.

Djunaedi, A. 2009. Pengaruh Jenis dan Dosis Pupuk Bokashi terhadap Pertumbuhan dan Hasil Kacang Panjang (Vigna sinensis L.). Universitas Trunojoyo. Madura.

Erwiyono. 1994. Pengaruh pemberian pupuk kandang dan aerasi terhadap mutu kompos limbah organik pabrik kertas. Jurnal Mikrobiologi Indonesia. Vol.2. (3). Pusat Penelitian Bioteknologi Perkebunan Bogor.

Firoz, Z. A. 2009. Impact of nitrogen and phosphorus on the growth and yield of okra (Abelmoschus esculentus L. Moench) in hill slope condition. Bang. J. Agril. Res.34 (4): 713-722.

Gardner, F. P., R.B Pearce dan R. L. Mitchell. 1991. Fisiologi Tanaman Budidaya. UI Press. Jakarta.

Ginting, R. C. B., R. Sarawati dan E. Husen. 1996. Pupuk Organik dan Pupuk Hayati. Balai Besar Litbang Sumber Daya Lahan Pertanian. Bogor.

Hardjowigeno, S. 2003. Ilmu Tanah. PT. Mediyatama Sarana Perkasa. Jakarta.

Khan, N. A. M. Khan., H. R. Ansyari dan Samiullah. 2002. Auxin and defoliation effects on photosynthesis and ethylene evolution in mustard. J. Scientia Horicultura. 96 (2002): 43-51.

Lakitan, B. 1996. Fisiologi Pertumbuhan dan Perkembangan Tanaman. P.T. Raja Grafindo Persada. Jakarta.

Lim, T. K. 2012. Edible Medicinal and Non- Medicinal Plants : Fruits. Springer Science and Business Media B.V. 3 pp. 160.

Mariana, P., R. Sipayung, M. Sinuraya. 2012. Pertumbuhan dan pengaruh produksi bawang merah (Allium ascalonicum L.) dengan pemberian vermikompos dan urine domba. Jurnal Online Agroekoteknologi 1. (1): $15 \mathrm{hlm}$.

Mas’ud, P. 1993. Telaah Kesubura Tanah. Angkasa. Bandung.

Nadira, S., B. Hatidjah dan Nuraeni. 2009. Pertumbuhan dan hasil tanaman okra (Abelmoschus esculentus L. Moench) pada perlakuan pupuk dekaform dan defoliasi. J. Agrisains 10 (1): 10-15.

Nyanjang, R., A. A. Salim, Y. Rahmiati. 2003. Penggunaan Pupuk Majemuk NPK 25-7-7 terhadap Peningkatan Produksi Mutu pada Tanaman Teh Menghasilkan di tanah Andisol. PT. Perkebunan Nusantara XII Prosiding Teh. 
Suminarti, E. N. 2000. Pengaruh Jarak Tanam dan Defoliasi Daun terhadap Hasil Tanaman Jagung ( Zea mays) Varietas Bisma. Erlangga. Jakarta.

Sutedjo, M. M. 2010. Pupuk dan Cara Pemupukan. Rineka Cipta. Jakarta.

Tamtomo, F. S, Rahayu dan A. Suyanto. 2015. Pengaruh aplikasi kompos jerami dan abu sekam padi terhadap produksi dan kadar pati ubi jalar. Jurnal Agrosains. 12 (2):1-7. 